\title{
Family structure of F5 soybeans lines derived from soybean varieties with the main differences on seed size and maturity traits
}

\author{
HERU KUSWANTORO ${ }^{1, \bullet}$, RINA ARTARI ${ }^{1}$, RUDI ISWANTO ${ }^{1}$, HILYATUL IMANI ${ }^{2}$ \\ ${ }^{1}$ Indonesian Legume and Tuber Crops Research Institute, Indonesian Agency for Agricultural Research and Development. Jl. Raya Kendalpayak Km. 8, \\ Malang 65162, East Java, Indonesia. Tel.: +62-341-801468, Fax.: +62-341-801496, `email: herukusw@ gmail.com \\ ${ }^{2}$ Department of Statistics, Faculty of Mathematics and Natural Sciences, Institut Pertanian Bogor. Jl. Meranti, Kampus IPB Dramaga, Bogor 16680, West \\ Java, Indonesia
}

Manuscript received: 24 February 2020. Revision accepted: 16 May 2020.

\begin{abstract}
Kuswantoro H, Artari R, Iswanto R, Imani H. 2020. Family structure of F5 soybeans lines derived from soybean varieties with the main differences in seed size and maturity traits. Biodiversitas 21: 2576-2585. The success of breeding programs depends on the availability of genetic resources with high genetic diversity. Genetic diversity plays a role in relationship between genotypes or within a group of genotypes. Seed size and the days to maturity are the main traits to develop a new superior variety for better seed quality and quantity. The plant materials consisted of eight F5 families originating from a combination of crossbreeding between four Korean soybean varieties (Daehwang, Daemang, Daewon, and Songhak) and two Indonesian soybean varieties (Argomulyo and Lawit). The main traits of four Korean soybean varieties are similar to each other, i.e. large seed size and early maturity. The two Indonesian soybean varieties differ on seed size and maturity. Argomulyo has a large seed size and early maturity, while Lawit has a small seed size and late maturity. Agronomic data, such as days to $50 \%$ flowering, days to maturity, days to harvesting, plant height, number of branches, number of reproductive nodes, number of filled pods, number of unfilled pods, seed yield per plant, 100 seeds weight, and seed yield per plot, were analyzed using R programs to form the groups. The grouping was based on principal component analysis. The results showed that the family structure of a cross was determined by the characteristics of the crossed genotypes. The family structures with Argomulyo as male parents were more influenced by 100 seeds weight, while the family structures with Lawit as male parents were more influenced by days to maturity. No family structure was formed with a large seed size on crossing with Lawit as the male parent. In this population, high seed yield as the main target of plant breeding was obtained on crossing of Daemang with Lawit.
\end{abstract}

Keywords: Maturity, seed size, structure, soybean

\section{INTRODUCTION}

Seed size and days to maturity play an important role in soybean breeding in Indonesia. Seed size is needed in the acceptability of the stakeholders such as farmers and food industries that require a certain seed size. The tempeh industry, in general, prefers large-seeded soybeans because it can increase the tempeh's appearance. The tofu industry can use all soybeans, both small and large seeds (Krisdiana 2007). The focus of the tofu industry is on seed protein content because soybeans with high protein content produce more tofu. Small seeded soybeans contain more protein so it is suitable for tofu (James and Yang 2016; Suwa et al. 2018). Seed size is related to the absence of 11SA4 globulin polypeptide that also can improve the tofu gel properties (James and Yang 2016).

The days to maturity is important in soybean breeding program because it is related to land efficiency and the abiotic and biotic stresses faced by soybeans in the field. Usually, the early days to maturity is preferred by farmers because it allows more frequent planting so that farmers' income increases. Genes controlling the days to maturity differ from the days to flowering (Miranda et al. 2020). Therefore, the development of superior soybean variety for early days to flowering can be carried out so that the duration of pod filling is longer and the seed production is higher. Shorter days to maturity also minimize attacks by pests and diseases because the plant faces pests and diseases in short period. The days to maturity is not correlated with protein content (Kurasch et al. 2017), which allows obtaining high protein content in both early and late days to maturity.

The breeding program is an important activity to produce new superior varieties of soybeans that are suitable for special purposes with the desired characteristics. The success of breeding programs depends on the availability of genetic resources that have a high diversity. Crossing soybean genotypes with high genetic distance and far kinship relations accelerates the breeding process (Liu et al. 2017; Gwinner et al. 2017) and vice versa. Furthermore, low genetic diversity can lead to a decrease in genetic potential, increase susceptibility to biotic stress, and decrease the adaptability to environmental changes (Gwinner et al. 2017). Several methods can be used to determine genetic diversity including cluster analysis used to classify diversity in germplasm collections based on similarity levels, grouping individuals with the same trait in one group, and separating individuals with different traits in different groups (El-Hashash 2016).

Genetic diversity and kinship relationship can be identified based on differences in morphological and agronomic performance, pedigree information, geographic 
origin, isozymes and DNA markers (He et al. 2012; Salimi et al. 2012; Liu et al. 2017; Gwinner et al. 2017). The relationship between genotypes can be determined by grouping based on morphological, agronomic, and molecular traits. The close genotypes have similarities based on the traits used for these groupings. Kinship analysis based on morphological traits will be more accurate when using traits with high heritability values. Plant height, number of branches, number of pods per plant, and 100-seed weight show the high genotypic coefficient of variance, heritability, and genetic advance, so that these traits can be used for phenotypic selection criteria to obtain high soybean yield (Malek et al. 2014).

Genetic diversity of plant quantitative trait is influenced by genetics and environmental factors. The genetic factor can be identified accurately by molecular markers. Liu et al. (2017) reported that based on SNP markers, the genetic diversity of soybeans in China and America was different. Furthermore, it was reported that genetic diversity was related to the geographical origin of the soybeans (Liu et al. 2017). Analysis based on molecular markers is very important because molecular markers are not influenced by environmental factors. However, diversity analysis based on the agronomic trait is also important because this agronomic diversity is directly faced by plant breeders in genetic improvement. Therefore, if the genetic diversity in germplasm collections is low based on agronomic traits (Gwinner et al. 2017), the genetic source is needed for future breeding programs. This study was to investigate family structure of F5 soybeans lines derived from soybean varieties with the main differences in seed size and maturity traits.

\section{MATERIALS AND METHOD}

\section{Study sites}

The F5 soybean lines were grown from March to June 2017 at Jambegede Research Station of Malang, East Java, Indonesia. The coordinate of the research location was $8^{\circ} 10^{\prime} 30^{\prime \prime} \mathrm{S}$ and $112^{\circ} 33^{\prime} 32.4^{\prime \prime}$ E. The soil type was Inceptisol.

\section{Plant materials}

Plant material consisted of eight F5 families derived from the crosses of Daehwang $\times$ Argomulyo (Dh/A), Daehwang $\times$ Lawit $(\mathrm{Dh} / \mathrm{L})$, Daemang $\times$ Argomulyo (Dg/A), Daemang $\times$ Lawit $(\mathrm{Dm} / \mathrm{L})$, Daewon $\times$ Argomulyo (Dw/A), Daewon $\times$ Lawit $(\mathrm{Dw} / \mathrm{L})$, Songhak $\times$ Argomulyo $(\mathrm{Sh} / \mathrm{A})$, dan Songhak $\times$ Lawit $(\mathrm{Sh} / \mathrm{L})$. Daehwang, Daemang, Daewon, and Songhak have introduced varieties from Korea. All four varieties have a large seed size and early maturity. Argomulyo is an Indonesian superior variety with large seeds and early maturity. Although classified as large seed size, the seed of Argomulyo is smaller than those of the four introduced varieties from Korea. Lawit is an Indonesian superior variety with small seed size and late maturity.

\section{Design and cultural practice}

Each F5 family consisted of 60 lines, so there were 480 lines. Each line was planted in a row along $3 \mathrm{~m}$. The seeds were planted with a spacing of $40 \mathrm{~cm} \times 15 \mathrm{~cm}$. Fertilization was conducted with $100 \mathrm{~kg}$ Urea, $50 \mathrm{~kg} \mathrm{SP36}$, and $50 \mathrm{~kg}$ $\mathrm{KCl}$ and $1 \mathrm{t} \mathrm{ha}^{-1}$ manure. SP36 and $\mathrm{KCl}$ fertilizing were done at the planting date, while Urea fertilizing was done twice, i.e. $50 \mathrm{~kg}$ at planting date and $50 \mathrm{~kg}$ before the flowering.

\section{Weather data}

The weather data is presented in Table 1. The rainfall was fluctuating across the four months, where the highest rainfall occurred in April (244 mm) and the lowest rainfall was in May $(17 \mathrm{~mm})$. The relative humidity and temperature were relatively stable. The relative humidity averaged at $83.8 \%$ with the highest was in May $(85.3 \%$ ) and the lowest was in March $(82.0 \%)$. The highest temperature was in March $\left(27.5^{\circ} \mathrm{C}\right)$, while the lowest temperature was in June $\left(25.0^{\circ} \mathrm{C}\right)$ with an average of $26.4^{\circ} \mathrm{C}$.

\section{Data analysis}

The observed variable were days to $50 \%$ flowering, days to maturity, days to harvesting, plant height, number of branches, number of productive nodes, number of filled pods, number of unfilled pods, seed yield per plant $(\mathrm{g})$, 100 -seed weight $(\mathrm{g})$, and seed yield per plot $(\mathrm{g})$. The days to maturity was recorded when most pods yellowing and the leaves falling, while the days to harvesting was recorded when all pods became brown and most leaves falling. The data were analyzed using the $\mathrm{R}$ program. Family structure was assessed based on the distribution of F5 soybean lines in the quadrant formed from principal component analysis (PCA) and the contribution of each trait to the soybean lines.

Table 1. Weather conditions data at Jambegede Research Station from March to June 2017

\begin{tabular}{lccc}
\hline Month & $\begin{array}{c}\text { Rainfall } \\
(\mathbf{m m})\end{array}$ & $\begin{array}{c}\text { Relative } \\
\text { humidity }(\boldsymbol{\%})\end{array}$ & $\begin{array}{c}\text { Temperature } \\
\left({ }^{\circ} \mathbf{C}\right)\end{array}$ \\
\hline March & 133 & 82.0 & 27.5 \\
April & 244 & 83.3 & 26.7 \\
May & 17 & 85.3 & 26.2 \\
June & 79 & 84.4 & 25.0 \\
Average & 118.3 & 83.8 & 26,4 \\
\hline
\end{tabular}




\section{RESULTS AND DISCUSSION}

The days to flowering of the eight families ranged from 32.80-35.83 days after planting (DAP). The shortest days to flowering was reached by the family of the Dw/A, while the longest was achieved by the family of the Dg/A (Table 2). In the previous study, the days to flowering of Daehwang, Daemang, Daewon, and Songhak were 30, 28, 27 , and 32 DAP, respectively (Kuswantoro et al. 2014), while the days to flowering of Argomulyo and Lawit were 35 and 40 DAP, respectively (Balitkabi 2016). The crossing with Argomulyo as a male parent leads to shorter days to $50 \%$ flowering rather than Korean varieties as the female parent. Besides, crossing with Argomulyo showed more diverse days to flowering than crossing with Lawit. Families with shortest days to flowering also had shortest days to maturity. However, the family with the highest days to maturity was not achieved by the family with the longest days to maturity (Table 2). The days to maturity of Daehwang, Daemang, Daewon, and Songhak were 81, 84, 82, and 77, respectively (Kuswantoro et al. 2014), while the days to maturity of Argomulyo and Lawit was 77 DAP (Krisnawati and Adie 2015) and 84 (Balitkabi 2016). However, the days to maturity are influenced by environmental factors, including rainfall wherein high rainfall the days to maturity becomes longer (Kuswantoro 2018). Teixeira et al. (2017) reported that the days to maturity are controlled by two genes.

In general, the plant height of the families with Lawit as the male parent was higher than with Argomulyo. Sh/L was the family with the highest plant height (Table 2). Dg/A had the highest plant height after Sh/L. The number of branches in $\mathrm{Dg} / \mathrm{A}$ was also the highest as compared to other families. Sh/L had the least number of branches despite its highest plant height. The introduced varieties from Korea generally have relatively short plant heights if planted in tropical climates (Kuswantoro et al. 2014). Plant height in both families was more influenced by Argomulyo and Lawit than the introduced varieties from Korea. Plant height is influenced by the environment. In suitable conditions, Lawit can reach around $70 \mathrm{~cm}$ plant height (Kuswantoro 2018). In subtropical regions like Korea, varieties from Korea can reach more than $70 \mathrm{~cm}$ plant height. The high environmental influence on plant height due to the polygenic genes controlling this trait. Teixeira et al. (2017) stated that plant height was controlled by 12 genes.

The highest number of productive nodes was reached by $\mathrm{Dg} / \mathrm{A}$ and the least was reached by Dw/A. The family with Daemang as a female parent produced more number of productive nodes than those with other Korean varieties (Table 2). The families with Daewon as a female parent produced branches with various number of reproductive nodes. This may be due to the gene interactions controlling the number of productive nodes. Thakare et al. (2017) reported that the number of reproductive nodes was controlled by additives and non-additives genes. It explains that there is no consistency in the number of reproductive nodes. In general, families with a large number of reproductive nodes also had large numbers of filled pods. This is because pods appear in reproductive nodes. The number of unfilled pods in general also followed the number of filled pods. An exception occurred in families with Daehwang as female parents which produced a greater number of unfilled pods when Argomulyo as male parents, even though the number of filled pods is the same as Lawit as female parents. This might be due to Argomulyo's tendency to produce more unfilled pods than Lawit. The number of pods is controlled by six genes (Teixeira et al. 2017) and has high heritability (Malek et al. 2014) causing this trait is low influenced by the environment.

Families with Argomulyo as a male parent produced a higher 100-seed weight than that with Lawit as the male parent. The seed size of Argomulyo is bigger than Lawit, so all seeds of Argomulyo offsprings were bigger than Lawit (Table 2). The family with the largest seed size was shown by Dw/A, while the smallest was shown by Sh/L. Songhak has the smallest seed size compared to the three Korean varieties (Kuswantoro et al. 2014), thus causing the offspring to have smaller seeds. Some authors (Hakim and Suyamto 2017; Sundaram et al. 2019) reported that the small seed was controlled by dominant gene (s) while the large seed was controlled by recessive gene (s). Therefore, crossings involving small-seeded genotypes would produce small-seeded soybeans.

Seed yield per plant is a combination of the number of filled pods and 100 seeds weight. In general, the higher number of filled pods and 100-seed weight produce a high seeds yield per plant. A similar result was also reported by (Sreenivasa et al. 2019), where seed yield, number of filled pods, and 100 seed weight were in the same quadrant. However, in the seed yield per plot, the population is very influential. In this study, the yield of seeds was also determined by its population. Families with small seed sizes produced higher seed yields per plot (Table 2). It is assumed that population size in families with small seed sizes was higher than populations with large seed sizes. Some studies also report that the small-seeded size soybean lines have higher seed yield than large-seeded soybean lines (Al-Hadi et al. 2017; Giordani et al. 2019). It is because the reproductive duration affects the potential yield of soybean (Xavier et al. 2017). Seed with higher vigor produced higher seed yield due to a higher plant population density (Caverzan 2018). Dg/A was the family with large seed size which suppose to decline in population density and lead to reduce seed yield. However, Dg/A had the highest seed yield per plot. This family might have the ability to maintain its seed vigor, even though the seed size was large. $\mathrm{Dg} / \mathrm{A}$ and $\mathrm{Dg} / \mathrm{L}$ had the highest seed yield than other families. These two families were derived from Daemang as female parent. Therefore, Daemang can be used as a female parent to develop high yielding soybean variety. 
Table 2. Performance of agronomical traits of soybean F5 family

\begin{tabular}{|c|c|c|c|c|c|c|c|c|c|c|c|}
\hline Family & $\begin{array}{c}\text { Days to 50\% } \\
\text { flowering } \\
\text { (DAP) }\end{array}$ & $\begin{array}{c}\text { Days to } \\
\text { maturity } \\
\text { (DAP) }\end{array}$ & $\begin{array}{c}\text { Days to } \\
\text { harvesting } \\
\text { (DAP) }\end{array}$ & $\begin{array}{l}\text { Plant height } \\
\text { (cm) }\end{array}$ & $\begin{array}{l}\text { Number of } \\
\text { branches }\end{array}$ & $\begin{array}{c}\text { Number of } \\
\text { reproductive } \\
\text { nodes }\end{array}$ & $\begin{array}{l}\text { Number of } \\
\text { filled pods }\end{array}$ & $\begin{array}{l}\text { Number of } \\
\text { unfilled pods }\end{array}$ & $\begin{array}{l}\text { Seed yield per } \\
\text { plant (g) }\end{array}$ & $\begin{array}{c}\text { 100-seed } \\
\text { weight (g) }\end{array}$ & $\begin{array}{l}\text { Seed yield } \\
\text { per plot }(\mathrm{g})\end{array}$ \\
\hline $\mathrm{Dh} / \mathrm{A}$ & $33.31 \pm 1.32$ & $70.74 \pm 1.41$ & $74.66 \pm 1.50$ & $37.60 \pm 6.27$ & $3.02 \pm 0.50$ & $13.91 \pm 2.11$ & $25.33 \pm 4.46$ & $1.56 \pm 0.68$ & $7.53 \pm 1.19$ & $14.60 \pm 1.37$ & $86.12 \pm 42.31$ \\
\hline $\mathrm{Dh} / \mathrm{L}$ & $34.91 \pm 1.74$ & $71.43 \pm 1.88$ & $75.47 \pm 1.86$ & $49.09 \pm 10.91$ & $2.76 \pm 1.02$ & $14.12 \pm 4.58$ & & $0.93 \pm 0.66$ & $6.12 \pm 1.90$ & $11.96 \pm 1.51$ & \pm 71.34 \\
\hline $\mathrm{Dg} / \mathrm{A}$ & $35.83 \pm 1.51$ & $71.31 \pm 1.16$ & $75.21 \pm 1.09$ & $61.20 \pm 13.02$ & $4.32 \pm 1.02$ & $17.61 \pm 4.41$ & $30.17 \pm 8.01$ & $1.05 \pm 0.63$ & $8.58 \pm 2.32$ & $14.29 \pm 1.50$ & $135.22 \pm 61.04$ \\
\hline $\mathrm{Dg} / \mathrm{L}$ & $34.89 \pm 1.55$ & $73.65 \pm 1.50$ & $77.53 \pm 1.26$ & $43.65 \pm 7.73$ & $3.39 \pm 0.71$ & $16.22 \pm 2.91$ & $33.11 \pm 7.05$ & $1.41 \pm 0.63$ & $7.58 \pm 1.74$ & $11.51 \pm 1.58$ & $111.34 \pm 53.19$ \\
\hline Dw/A & $32.80 \pm 1.09$ & $70.29 \pm 1.90$ & $74.22 \pm 1.91$ & $37.38 \pm 7.03$ & $2.54 \pm 0.53$ & $12.29 \pm 2.45$ & $22.93 \pm 6.62$ & $1.24 \pm 0.68$ & $6.65 \pm 1.63$ & $14.75 \pm 1.77$ & $85.46 \pm 48.33$ \\
\hline Dw/L & $34.56 \pm 2.26$ & $73.02 \pm 1.84$ & $76.93 \pm 1.82$ & $48.37 \pm 10.05$ & $3.21 \pm 0.78$ & $17.11 \pm 3.38$ & $37.67 \pm 7.29$ & $1.36 \pm 0.73$ & $8.46 \pm 1.92$ & $11.21 \pm 1.06$ & $92.07 \pm 47.12$ \\
\hline $\mathrm{Sh} / \mathrm{A}$ & $33.00 \pm 1.44$ & $70.57 \pm 1.57$ & $74.41 \pm 1.51$ & $41.91 \pm 7.24$ & $2.96 \pm 0.72$ & $14.10 \pm 2.50$ & $27.82 \pm 6.49$ & $1.81 \pm 0.86$ & $7.28 \pm 1.52$ & $13.23 \pm 1.49$ & $91.05 \pm 42.74$ \\
\hline $\mathrm{Sh} / \mathrm{L}$ & $35.02 \pm 1.51$ & $71.57 \pm 1.07$ & $75.57 \pm 1.07$ & $65.30 \pm 10.78$ & $2.84 \pm 0.62$ & $15.90 \pm 2.31$ & $32.40 \pm 6.92$ & $1.83 \pm 0.71$ & $6.67 \pm 2.31$ & $10.19 \pm 2.10$ & $99.08 \pm 50.49$ \\
\hline
\end{tabular}

Songhak/Argomulyo, $\mathrm{Sh} / \mathrm{L}=$ Songhak/Lawit 
Table 3. Eigen analysis of the correlation matrix

\begin{tabular}{llllllllllll}
\hline & PCA1 & PCA2 & PCA3 & PCA4 & PCA5 & PCA6 & PCA7 & PCA8 & PCA9 & PCA10 & PCA11 \\
\hline Eigenvalue & 4.2980 & 1.6916 & 1.3879 & 1.2825 & 0.7698 & 0.6821 & 0.4194 & 0.3396 & 0.1006 & 0.0177 & 0.0107 \\
Proportion & 0.391 & 0.154 & 0.126 & 0.117 & 0.070 & 0.062 & 0.038 & 0.031 & 0.009 & 0.002 & 0.001 \\
Cumulative & 0.391 & 0.545 & 0.671 & 0.787 & 0.857 & 0.919 & 0.957 & 0.988 & 0.997 & 0.999 & 1.000 \\
\hline
\end{tabular}

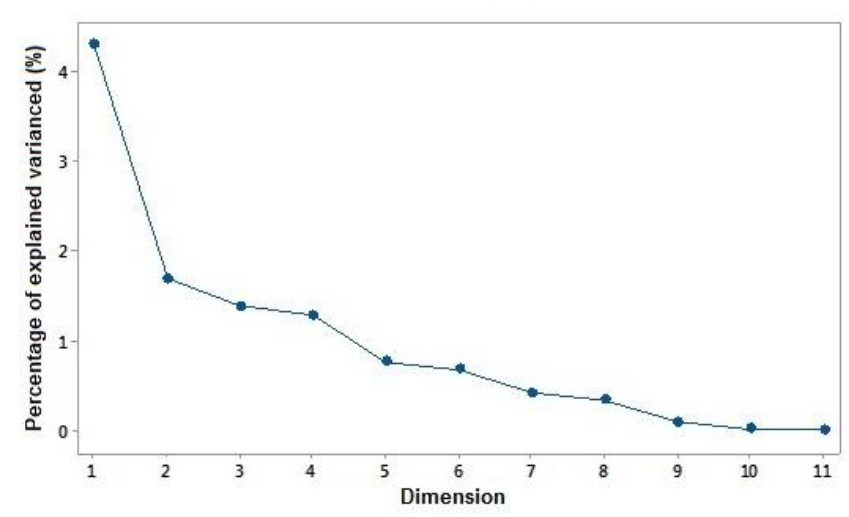

Figure 1. Scree plot of eleven agronomical traits of eight F5 families

The determination of the number of principal components was done by a scree plot (Figure 1). Based on the scree plot obtained, the highest slopes were achieved at PCA1 and PCA2. In the next PCAs, the slope was less steep. From PCA2 to PCA11, the slope is not high. Therefore, in this study, the limit of PCA used was two PCA. The cumulative eigenvalue obtained by these two PCAs reached $54.5 \%$ (Table 3). The Eigenvector for each PC presented in Table 4 showed that each PC had main traits. The highest trait in $\mathrm{PC} 1$ was the number of reproductive nodes, while the highest trait in PC2 was seed yield per plant and 100 seeds weight. If the PCA is limited up to $78.7 \%$, the 100 -seed weight had the most contribution to the observed variability than other traits. Kuswantoro (2019) also reported broad variability on 100-seed weight.

Figure 2 is a plot of each soybean lines from eight families based on the principal component analysis (PCA). The plot is a two-dimensional plot between PCA1 and PCA2. Based on this plot, the distribution of each family can be displayed. The soybean lines of $\mathrm{Dg} / \mathrm{L}$ were spread throughout the four quadrants and the most distribution was in quadrant I. The Dh/A family was spread in quadrants II and III, but it was most commonly found in quadrant II. The $\mathrm{Dh} / \mathrm{L}$ family distributed throughout the four quadrants, but quadrants III and IV had the most soybean lines from this family. The Dw/A family also distributed throughout the four quadrants, but most family members were found in Quafran II and III. The Sh/A family spread throughout all quadrants except quadrant IV and most commonly found in quadrant II. The Sh/L family spread across all quadrants and were most commonly found in quadrant IV. The genotype distribution of each family in Figure 2 occurs based on the similarity of traits possessed by the genotypes. This grouping is similar to clustering, where every genotype is identified through its traits. According to Kumar et al. (2018) clustering method can be used to determine the parents for crossing. Cluster analysis can also be used to determine the genetic diversity of population of soybean genotypes (Salimi et al. 2012).

The contribution of each trait in each quadrant obtained from PCA1 and PCA2 is presented in Figure 3. In quadrant I there was no trait as the attribute of the lines in this quadrant. The main trait in quadrant II was days to harvesting, days to maturity, and days to $50 \%$ flowering. This quadrant was also contributed by plant height and seed yield per plot. However, the contribution of these two traits was relatively low. In quadrant III the highest contributing traits were the number of reproductive nodes, seed yield per plant, number of filled pods, and number of branches. The seed yield per plot also contributed to this quadrant, but the contribution was very low. Quadrant IV only had two traits, namely 100 -seed weight and the number of unfilled pods. The contribution of the number of unfilled pods in quadrant IV was very low. The highest contribution to the whole family was the number of reproductive nodes, seed yield per plant, and days to harvesting, while the lowest was achieved by the number of unfilled pods and seed yield per plot.

Each F5 family had different characteristics. Based on Figures 2 and 3 it can be concluded that in the $\mathrm{Dg} / \mathrm{L}$ family the main traits were the days to maturity and $50 \%$ flowering, as well as the seed yield per plot. In this study, the high vector of days to $50 \%$ flowering referred to the longer days to $50 \%$ flowering. This result contradicts with Mofokeng and Mashingaidze (2018) who reported early flowering and high seed yield per plot were grouped together. Dh/A only had two main traits as the attribute of this family, i.e. 100-seed weight and the number of unfilled pods. Dw/A and Sh/A families also had the main characteristic that similar to Dw/A, namely 100-seed weight and the number of unfilled pods. It seems that the crossing with Argomulyo as male parent produced offspring with high 100-seed weight and the number of unfilled pods as the main traits. However, this did not occur in Dg/A family which had more complete characteristics, such as seed yield per plant, number of branches, days to harvesting, number of filled pods, days to $50 \%$ flowering, plant height, and seed yield per plot. 
Table 4. Eigenvectors for eleven traits of eight F5 families

\begin{tabular}{llllllllllll}
\hline Variable & PC1 & PC2 & PC3 & PC4 & PC5 & PC6 & PC7 & PC8 & PC9 & PC10 & PC11 \\
\hline X1 & 0.320 & -0.197 & 0.264 & -0.022 & 0.407 & 0.403 & 0.197 & 0.647 & -0.061 & 0.010 & -0.010 \\
X2 & 0.313 & -0.416 & -0.346 & 0.259 & -0.113 & 0.116 & -0.016 & -0.136 & 0.025 & 0.704 & 0.038 \\
X3 & 0.315 & -0.420 & -0.343 & 0.244 & -0.114 & 0.116 & 0.019 & -0.132 & -0.008 & -0.708 & -0.029 \\
X4 & 0.266 & -0.125 & 0.544 & -0.183 & 0.020 & 0.139 & 0.420 & -0.614 & 0.104 & 0.010 & -0.000 \\
X5 & 0.366 & 0.290 & 0.108 & 0.072 & 0.176 & 0.210 & -0.647 & -0.131 & 0.503 & -0.028 & -0.017 \\
X6 & 0.424 & 0.237 & -0.006 & -0.115 & 0.110 & -0.076 & -0.255 & -0.159 & -0.801 & 0.013 & 0.009 \\
X7 & 0.396 & 0.188 & -0.196 & -0.226 & -0.074 & -0.381 & 0.254 & 0.148 & 0.208 & 0.036 & -0.661 \\
X8 & -0.024 & 0.086 & -0.268 & -0.636 & -0.413 & 0.586 & -0.022 & 0.028 & -0.004 & 0.005 & 0.012 \\
X9 & 0.323 & 0.474 & -0.211 & 0.122 & -0.099 & -0.090 & 0.400 & 0.095 & 0.151 & -0.026 & 0.633 \\
X10 & 0.176 & -0.046 & 0.479 & 0.212 & -0.758 & -0.090 & -0.156 & 0.286 & -0.057 & -0.002 & 0.001 \\
X11 & -0.150 & 0.432 & -0.037 & 0.552 & -0.066 & 0.487 & 0.227 & -0.111 & -0.141 & 0.020 & -0.399 \\
\hline
\end{tabular}

Note: $\mathrm{X} 1=$ days to $50 \%$ flowering; $\mathrm{X} 2=$ days to maturity; $\mathrm{X} 3=$ days to harvesting; $\mathrm{X} 4$ = plant height; $\mathrm{X} 5=$ number of branches; X6 = number of produtive nodes; $\mathrm{X} 7=$ number of filled pods; $\mathrm{X} 8=$ number of unfilled pods; $\mathrm{X} 9=$ seed yield per plant $(\mathrm{g}) ; \mathrm{X} 10=$ seed yield per plot (g); X11 = 100-seed weight $(\mathrm{g})$

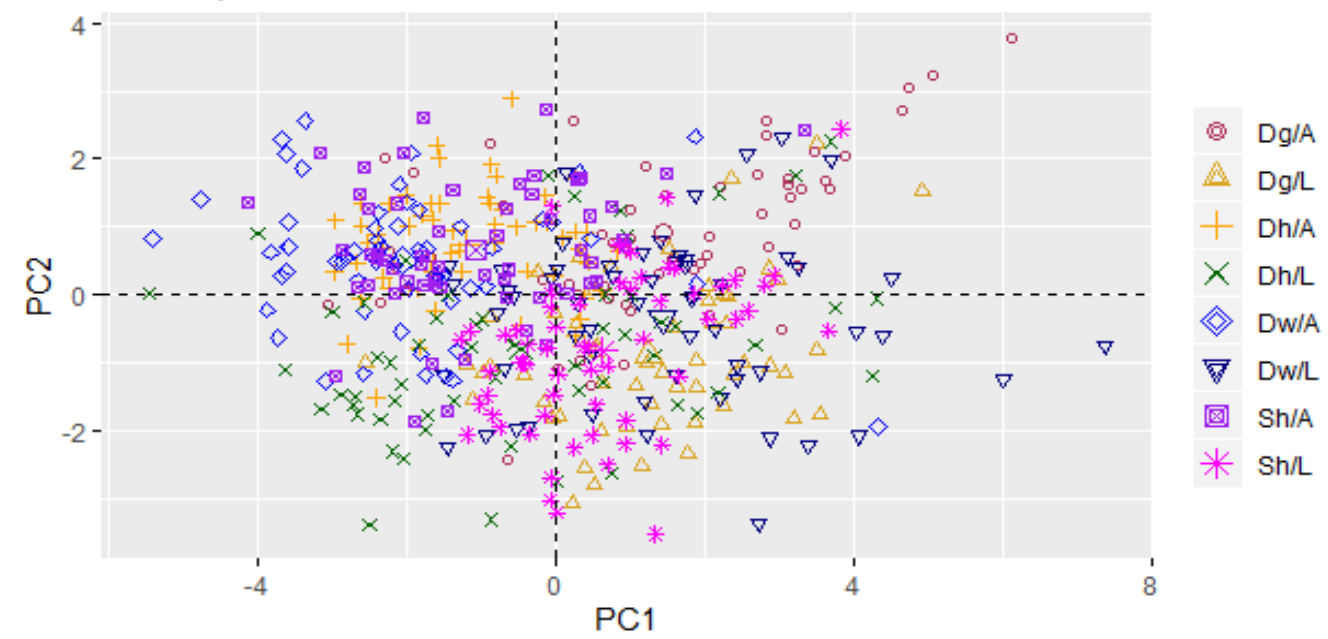

Figure 2. Distribution of soybean lines of eight F5 families

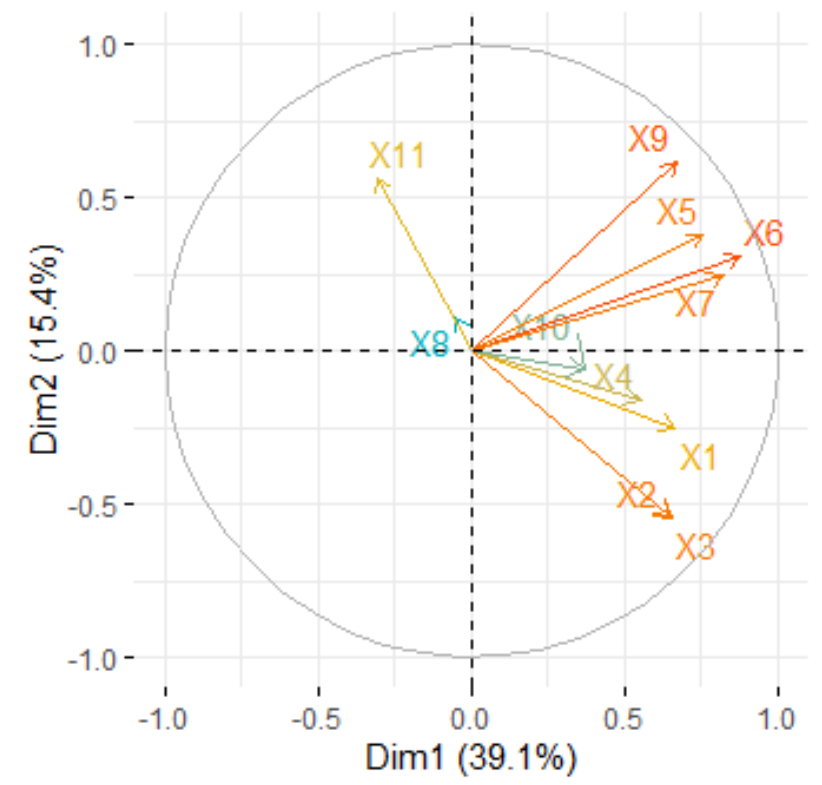

Figure 3. Contribution of the traits in each quadrant. $\mathrm{X} 1=$ days to $50 \%$ flowering; $\mathrm{X} 2$ = days to maturity; $\mathrm{X} 3$ = days to harvesting; $\mathrm{X} 4$ = plant height; $\mathrm{X} 5$ = number of branches; $\mathrm{X} 6$ = number of produtive nodes; $\mathrm{X} 7=$ number of filled pods; $\mathrm{X} 8=$ number of unfilled pods; $\mathrm{X} 9=$ seed yield per plant $(\mathrm{g}) ; \mathrm{X} 10=$ seed yield per plot $(\mathrm{g}) ; \mathrm{X} 11=100$-seed weight $(\mathrm{g})$

\section{Family structure of daehwang crosses}

In families with Daehwang as female parents, there was a slight interception between the families from Argomulyo (Dh/A) and Lawit (Dh/L) as male parents. The quadrants occupied by the two families were also relatively different. Crosses with Argomulyo produced offspring in quadrants III and IV, while crosses with Lawit produced offspring in quadrants I and II. However, crosses with Lawit produced lines that were more spread out than crosses with Argomulyo. The differences between the Dh/A and Dh/L families based on the biplot can be seen in Figure 4. The main attributes in $\mathrm{Dh} / \mathrm{A}$ family were large seed size (100 
seeds weight), the high number of unfilled pods, and seed yield per plant. Traits of 100-seed weight are effectively used as selection criteria because of high heritability (Kuswantoro et al. 2018; Kuswantoro 2019). The main attributes in the $\mathrm{Dh} / \mathrm{L}$ family were longer days to $50 \%$ flowering, maturity and harvesting, and high seed yield per plants and plot. Daehwang has 100-seed weight of $33.94 \mathrm{~g}$ and 4 unfilled pods which are higher than the three other Korean varieties (Kuswantoro et al. 2014). Therefore, the structure shown in the crossing with Argomulyo led to larger seed size because Argomulyo also has large seed size. The relatively large number of unfilled pods in the crossing with Argomulyo was more influenced by Daehwang because the number of unfilled pods of Argomulyo was small. In crossing with Lawit, seed size was generally small because seed size is controlled dominantly in small seed size (Hakim and Suyamto 2017; Sundaram et al. 2019).

\section{Family structure of Daemang crosses}

The family originating from a cross between Daemang and Argomulyo (Dg/A) was highly different from the Daemang and Lawit $(\mathrm{Dg} / \mathrm{L})$ crossings. Each of the crosses had certain attributes (Figure 5). The Dg/A family was more dominant in quadrants II and III, while the $\mathrm{Dg} / \mathrm{L}$ family tended to be in quadrants I and IV. The offspring distribution of $\mathrm{Dg} / \mathrm{A}$ was greater than that of the $\mathrm{Dg} / \mathrm{L}$. The offspring of $\mathrm{Dg} / \mathrm{A}$ had attributes of higher plant height, large seed size (100-seed weight), and a high number of branches. Plant height at this crossing was more influenced by Argomulyo because Daemang plant height is short (Kuswantoro et al. 2014). The offspring of the Daemang

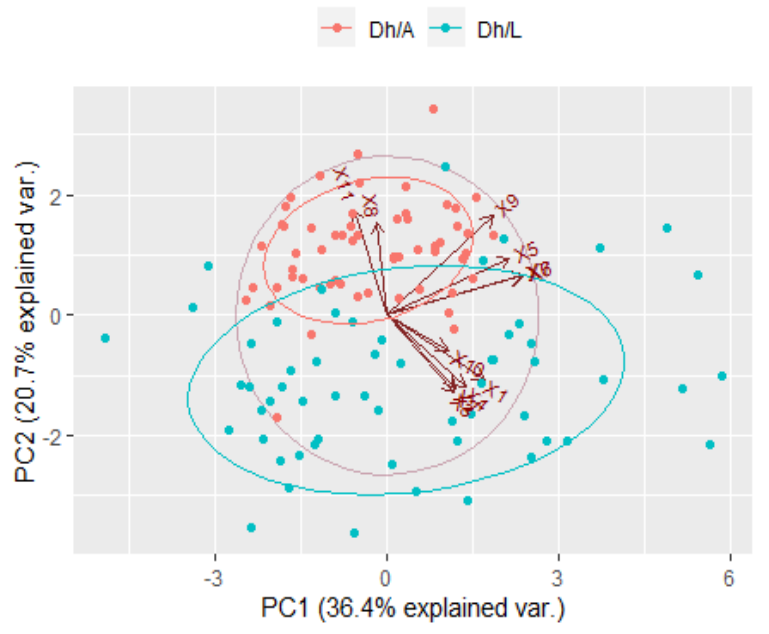

Figure 4. Biplot of Daewhang crosses with Argomulyo and Lawit. $\mathrm{X} 1=$ days to $50 \%$ flowering; $\mathrm{X} 2$ = days to maturity; $\mathrm{X} 3=$ days to harvesting; $\mathrm{X} 4=$ plant height; $\mathrm{X} 5=$ number of branches; $\mathrm{X} 6=$ number of produtive nodes; $\mathrm{X} 7=$ number of filled pods; $\mathrm{X} 8$ $=$ number of unfilled pods; $\mathrm{X} 9=$ seed yield per plant $(\mathrm{g}) ; \mathrm{X} 10=$ seed yield per plot $(\mathrm{g}) ; \mathrm{X} 11=100$-seed weight $(\mathrm{g})$ and Lawit crossings showed the characteristics of long days to maturity and harvesting, and a large number of unfilled pods. The long days to maturity and harvesting were more influenced by Lawit. In this crossing, there was no intersection which illustrates that the two families had a great genetic distance. Therefore, these two families can be used to create new genetic diversity. Crosses based on genetic distances between two families with far intercluster distance can produce broad-spectrum variability (Hormichon et al. 2018).

\section{Family structure of Daewon crosses}

Crosses using Daewon as female parents produced a different family structure between Agromulyo and Lawit as male parents. In the cross with Argomulyo as male parents, the offspring spread in quadrants I and IV. In contrast, crossing with Lawit as male parent produced offspring in quadrants II and III. In these crosses, the distribution of Dw/L was greater than Dw/A. Based on Figure 6, it can be seen that the characteristic possessed by Dw/A is the 100seed weight. Seed size is controlled by dominant genes (Thakare et al. 2017) with small seed sizes dominant against large seeds (Hakim and Suyamto 2017; Sundaram et al. 2019). In contrast to the Dw/A family that only had one distinguishing trait, the Dw/L family had complete traits of the long days to maturity and harvesting, the high number of branches, productive nodes, and filled pods, and high seed yield. The long days to maturity and harvesting were the weaknesses of this family because the duration needed to obtain seed yield become longer. Also, the small seed size is less favored by farmers and the tempeh industry in Indonesia (Krisdiana 2007).

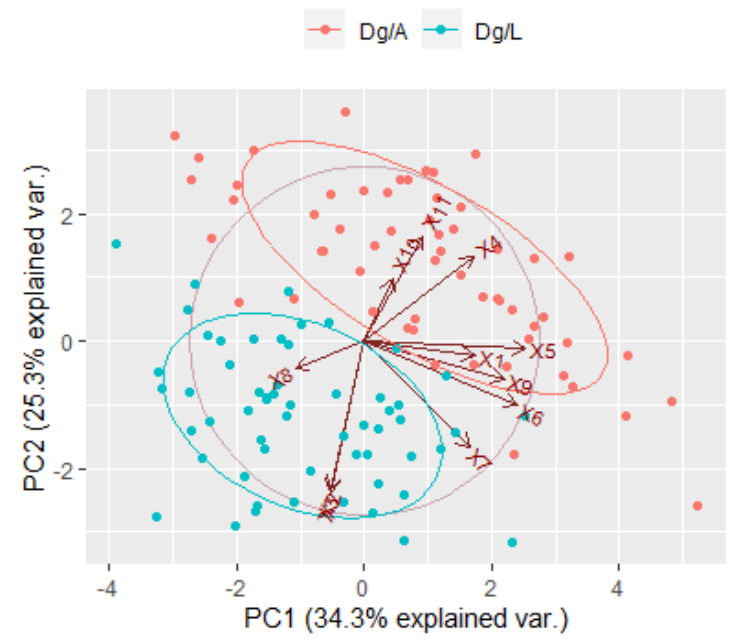

Figure 5. Biplot of Daemang crosses with Argomulyo and Lawit. $\mathrm{X} 1$ = days to $50 \%$ flowering; $\mathrm{X} 2=$ days to maturity; $\mathrm{X} 3=$ days to harvesting; X4 = plant height; X5 = number of branches; X6 = number of produtive nodes; $\mathrm{X} 7=$ number of filled pods; $\mathrm{X} 8=$ number of unfilled pods; $\mathrm{X} 9=$ seed yield per plant $(\mathrm{g}) ; \mathrm{X} 10=$ seed yield per plot $(\mathrm{g}) ; \mathrm{X} 11=100$-seed weight $(\mathrm{g})$ 


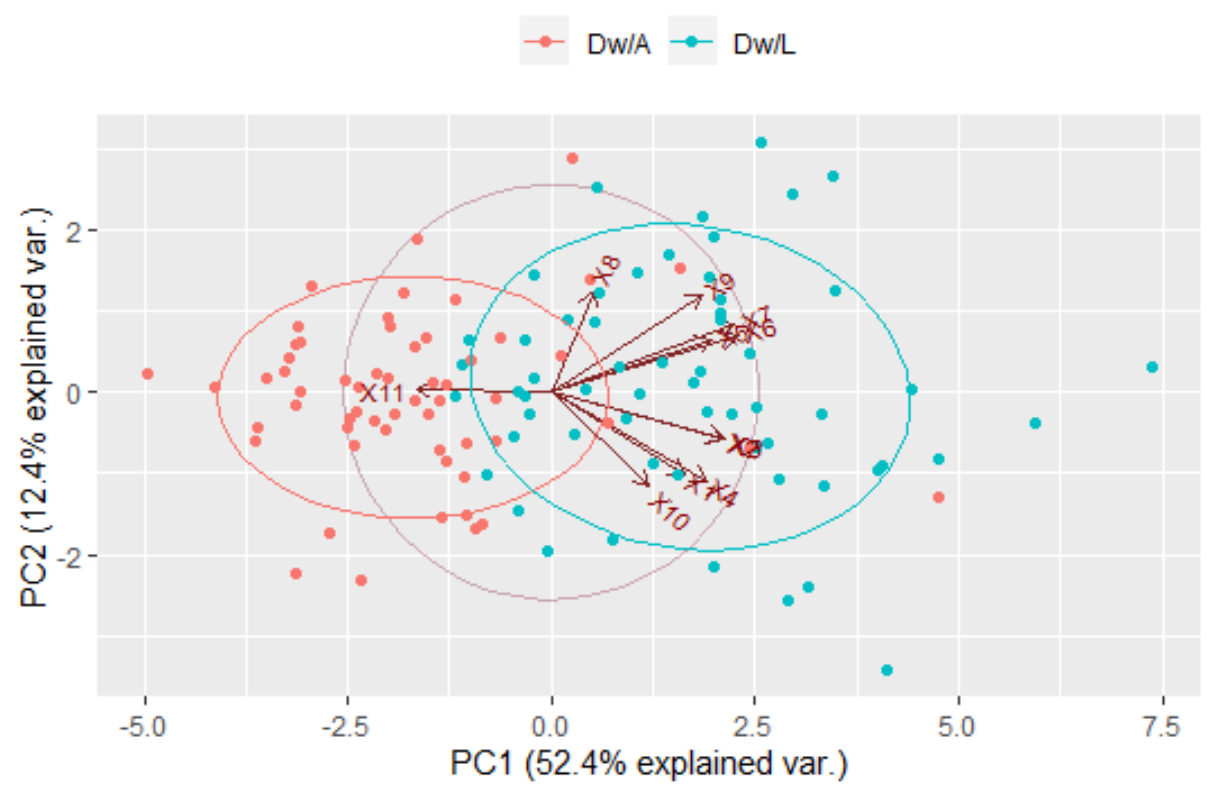

Figure 6. Biplot of Daewon crosses with Argomulyo and Lawit. $\mathrm{X} 1=$ days to $50 \%$ flowering; $\mathrm{X} 2=$ days to maturity; $\mathrm{X} 3=$ days to harvesting; $\mathrm{X} 4=$ plant height; $\mathrm{X} 5=$ number of branches; $\mathrm{X} 6=$ number of produtive nodes; $\mathrm{X} 7=$ number of filled pods; $\mathrm{X} 8=$ number of unfilled pods; $\mathrm{X} 9$ = seed yield per plant $(\mathrm{g}) ; \mathrm{X} 10=$ seed yield per plot $(\mathrm{g}) ; \mathrm{X} 11=100$-seed weight $(\mathrm{g})$

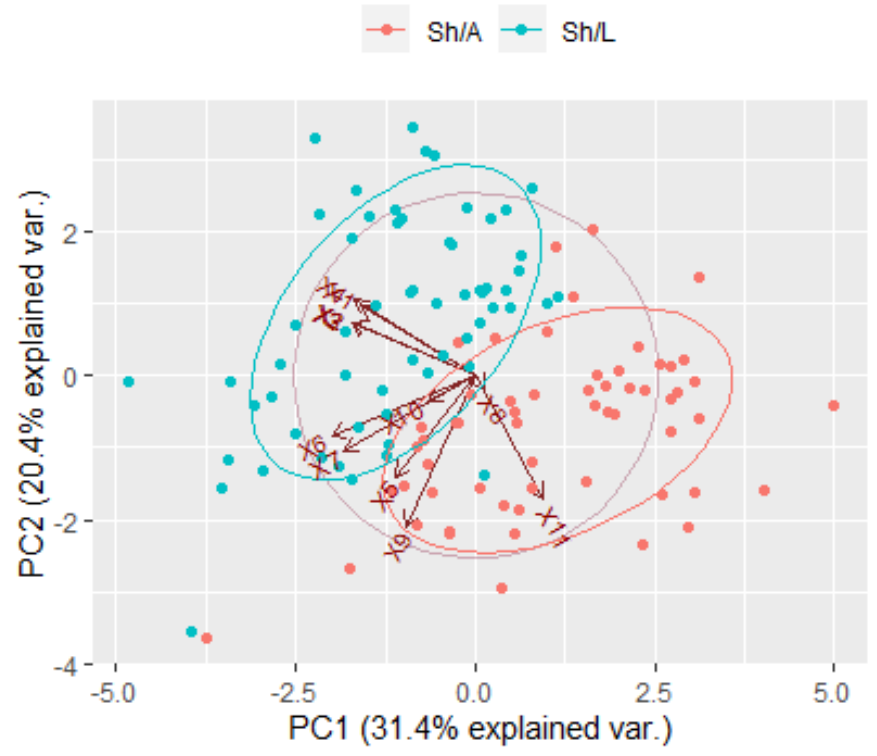

Figure 7. Biplot of Songhak crosses with Argomulyo and Lawit. X1 = days to 50\% flowering; $\mathrm{X} 2=$ days to maturity; $\mathrm{X} 3=\mathrm{days}$ to harvesting; X4 = plant height; X5 = number of branches; X6 = number of produtive nodes; X7 = number of filled pods; X8 = number of unfilled pods; $\mathrm{X} 9=$ seed yield per plant $(\mathrm{g}) ; \mathrm{X} 10=$ seed yield per plot $(\mathrm{g}) ; \mathrm{X} 11=100$-seed weight $(\mathrm{g})$

\section{Family structure of Songhak crosses}

In the crossing with Songhak, Argomulyo produced offspring which were in quadrants II and III, while Lawit produced offspring in quadrants I and IV. This condition was different from Daemang and Dahwang where in general the offspring produced by Argomulyo were in quadrants III and IV. In crossings where Songhak as the female parent, the distribution of offspring between Argomulyo and Lawit was also balanced. Based on Figure
7, Songhak crossed with Argomulyo had the characteristics of high 100-seed weight, and high seeds yield per plant. A similar result was also reported by Sreenivasa et al. (2019), where seed yield and 100-seed weight were in the same quadrant. Songhak which was crossed with Lawit had long days to $50 \%$ flowering, maturity, and harvesting, and high plant height. The phenology traits such as long days to $50 \%$ flowering, maturity, and harvesting are important in plant growth and development. These traits also can influence 
plant height as a vegetative trait. In this study, plant height $\mathrm{Sh} / \mathrm{L}$ was higher than Sh/A due to the phenology trait of Lawit was higher than Argomulyo that prolonged the growth duration of plant height. Plant height as a trait that had the main contribution was also reported by Mahbub et al. (2016). The days to flowering and 100-seed weight was governed by two genes (Sundaram et al. 2019) and high heritability (Kuswantoro et al. 2018). Therefore, days to $50 \%$ flowering and 100 seeds of weight can be used as selection criteria.

Based on the population structure of each family, the crosses with Argomulyo tended to produce families with large seed size, while crosses with Lawit produced long days to maturity and long days to harvesting. Thus, seed size played an important role in crosses using Argomulyo, while the days to maturity and the days to harvesting had an important role in crosses with Lawit. Family structure of one family differed to other family depending on the parents. In families with Daehwang as female parent, some traits such as number of branches, number of productive nodes, and seed yield per plant had similar effect in the family structure. The individual in $\mathrm{Dh} / \mathrm{L}$ was wider distributed than in Dh/A. Families with Songhak as female parents had similar structures to families with Daehwang but $\mathrm{Sh} / \mathrm{A}$ and $\mathrm{Sh} / \mathrm{L}$ were distributed equally. In families with Daemang, those three traits tended to build the structure of $\mathrm{Dg} / \mathrm{A}$ family. In families with Daewon, the structure of Dw/A was build by single trait, i.e. seed size, while the rests build Dw/L structure.

In conclusion, the family structure of a cross was determined by the characteristics of the crossed genotype. In crossing using Argomulyo, the family structure was more influenced by 100 -seed weight. Family structure in crossing with Lawit was more influenced by days to maturity and days to harvesting. No population structure was formed with a large seed size at crossing with Lawit. The highest seed yield was achieved by a family from the crossing of Argomulyo as a male parent and Daemang as the female parent. Crossing with Lawit as the male parent produced higher seed yield in three families. Daemang can be used as a female parent to develop high yielding soybean variety.

\section{REFERENCES}

Al-Hadi MAG, Islam MR, Karim MA, Islam MT. 2017. Morphophysiological characterization of soybean genotypes under subtropical $\begin{array}{llll}\text { environment. Genetika } 49 & \text { (1): 297-311. DOI: }\end{array}$ 10.2298/GENSR1701297A. [Indonesian]

Balitkabi. 2016. Description of Soybean Superior Variety. Balai Penelitian Tanaman Aneka Kacang dan Umbi, Malang. [Indonesian]

Caverzan A, Giacomin R, Müller M, Biazus C, Lângaro NC, Chavarria G. 2018. How does seed vigor affect soybean yield components? Agron J 110 (4): 1318-1327. DOI: 10.2134/agronj2017.11.0670

El-Hashash EF. 2016. Genetic diversity of soybean yield based on cluster and principal component analyses. J Adv Biol Biotechnol 10 (3):1-9.

Giordani W, Goncalves LSA, Moraes LAC, Ferreira LC, Neumaier N, Farias JRB, Nepomuceno AL, de Oliveira MCN, Mertz-Henning LM 2019. Identification of agronomical and morphological traits contributing to drought stress tolerance in soybean. Aust J Crop Sci 13 (1): $35-44$.
Gwinner R, Setotaw TA, Pasqual M, dos Santos JB, Zuffo AM, Zambiazzi EV, Bruzi AT. 2017. Genetic diversity in Brazilian soybean germplasm. Crop Breed Appl Biotechnol 17 (4): 373-381.

Hakim L, Suyamto. 2017. Gene action and heritability estimates of quantitative characters among lines derived from varietal crosses of soybean. Indones J Agric Sci 18 (1): 25-32.

He S, Wang Y, Volis S, Li D, Yi T. 2012. Genetic diversity and population structure: Implications for conservation of wild soybean (Glycine soja Sieb. Et Zucc) based on nuclear and chloroplast microsatellite variation. Intl J Mol Sci 13 (10): 12608-12628

Hormichon S, Devi H. Nanita, Devi Th. Renuka, Devi T. Sunanda, Karam Nilima, Devi L. Sophia. 2018. Genetic Diversity among soybean [Glycine $\max (\mathrm{L}$.$) Merrill] genotypes based on agro morphological$ characters under rainfed condition of Manipur. Clim Change Environ Sustain 6 (1): 41-45.

James AT, Yang AJ. 2016. Interactions of protein content and globulin subunit composition of soybean proteins in relation to tofu gel properties. Food Chem 194: 284-289. DOI: 10.1016/j.foodchem.2015.08.021

Krisdiana R. 2007. Tempeh and tofu industry preferences to size and color of soybean seed. Iptek Tanaman Pangan 2: 123-130. [Indonesian]

Krisnawati A, Adie MM. 2015. Seleksi populasi F5 kedelai berdasarkan karakter agronomis. Pros Sem Nas Masy Biodiv Indon 1: 434-437. [Indonesian]

Kumar S, Kumari V, V Kumar V. 2018. Assessment of genetic diversity in soybean [Glycine $\max$ (L.) Merrill] germplasm under NorthWestern Himalayas. J Pharmac Phytochem 7 (2): 2567-2570.

Kurasch AK, Hahn V, Leiser WL, Starck N, Würschum T. 2017. Phenotypic analysis of major agronomic traits in 1008 RILs from a diallel of early European soybean varieties. Crop Sci 57 (2): 726-738. DOI: $10.2135 /$ cropsci2016.05.0318

Kuswantoro H, Artari R, Rahajeng W, Ginting E, Supeno A. 2018. Genetic variability, heritability, and correlation of some agronomical characters of soybean varieties. Biosaintifika J Biol Biol Educ 10 (1): $9-15$.

Kuswantoro H, Sutrisno, Han WH, Lee PY, Cho YH, Baek IY. 2014. Performance of Korean soybean varieties in Indonesia. Korean J Int Agric 26 (2): 107-113.

Kuswantoro H. 2018. Effect of planting dates on growth, yield, and phenology of different soybean lines grown under tidal swampland. Pertanika J Trop Agric Sci 41 (3): 1261-1274.

Kuswantoro H. 2019. Performance, similarity, and genetic parameters of agronomical characters of soybean [Glycine max (L) Merrill.] germplasms. Agr Nat Resour 53 (3): 228-236. DOI: 10.34044/j.anres.2019.53.3.03

Liu Z, Li H, Wen Z, Fan X, Li Y, Guan R, Guo Y, Wang S, Wang D, Qiu L. 2017. Comparison of genetic diversity between Chinese and American soybean (Glycine $\max (\mathrm{L}$.)) accession revealed by highdensity SNPs. Front Plant Sci 8. DOI: 10.3389/fpls.2017.02014

Mahbub MM, Rahman MM, Hossain MS, Nahar L, Shirazy BJ. 2016. Morphophysiological variation in soybean (Glycine $\max (\mathrm{L}$.) Merrill). Amer-Eur J Agric Environ Sci 16 (2): 234-238.

Malek MA, Rafii MY, Afroz SS, Nath UK, Mondal MMA. 2014. Morphological characterization and assessment of genetic variability, character association, and divergence in soybean mutants. Sci World J. DOI: 10.1155/2014/968796

Miranda C, Scaboo A, Cober E, Denwar N, Bilyeu K. 2020. The effects and interaction of soybean maturity gene alleles controlling flowering time, maturity, and adaptation in tropical environments. BMC Plant Biol 20 (65). DOI: 10.1186/s12870-020-2276-y

Mofokeng MA, Mashingaidze K. 2018. Genetic differentiation of ARC soybean [Glycine max (L.) Merrill] accessions based on agronomic and nutritional quality traits. Agric Food Sci Res 5 (1): 6-22.

Salimi S, Lahiji HS, Abadi GM, Salimi S, Moradi S. 2012. Genetic diversity in soybean genotypes under drought stress conditions using factor analysis and cluster analysis. Appl Sci J 16 (4): 474-478.

Sreenivasa V, Lal SK, Talukdar A, Babu PK, Swamy HKM, Rathod DR, Yadav RR, Poonia S, Bhat KV, Viswanathan C. 2019. Evaluation of soybean germplasm lines for agro-morphological traits and terminal drought tolerance. Intl J Curr Microbiol Appl Sci 8 (4): 105-127.

Sundaram P, Samineni S, Sajja SB, Roy C, Singh SP, Joshi P, Gaur PM. 2019. Inheritance and relationships of flowering time and seed size in Kabuli chickpea. Euphytica 215: 144. DOI: 10.1007/s10681-0192464-8

Suwa R, Matsumora K, Higa M, Jaiphong T, Gima S, Ono T, Uehara N, Watanabe K, Kawamitsu Y, Onaga Y, Miyazato S. 2018. 
Investigation of fundamental seed features of three Okinawa local soybean (Glycine max) varieties. Trop Agric Dev 62 (4): 167-176.

Teixeira FG, Hamawaki OT, Nogueira AP, Hamawaki RL, Hamawaki CD, Mattos TP, Silveira IC, Medeiros LA. 2017. Inheritance of precocity and of agronomic characters in soybean. Genet Mol Res 16 (4): gmr16039842. https://www.geneticsmr.com/sites/default/files/articles/year2017/vol1 6-4/pdf/inheritance-of-precocity-and-of-agronomic-characters-insoybean.pdf
Thakare DS, Chimote VP, Deshmukh MP, Bhailume MS, Adsul AT, 2017. Inheritance of yield and yield components in soybean (Glycine $\max$ (L.) Merrill.) Electron J Plant Breed 8 (1): 176-181

Xavier A, Hall B, Casteel S, Muir W, Rainey KM. 2017. Using unsupervised learning techniques to assess interactions among complex traits in soybeans. Euphytica 213: 200. DOI: 10.1007/s10681-017-1975-4 